\title{
Acculturating Stress, Language Anxiety and Procrastination of International Students in the Academic Settings
}

\section{Акультураційний стрес, мовна тривожність та прокрастинація в іноземних студентів в академічному середовищі}

\section{Larysa Zasiekina ${ }^{1}$ \\ Dr. in Psychology, \\ Professor}

\section{Лариса Засскіна ${ }^{1}$}

доктор психологічних наук, професор

\footnotetext{
E-mail: lora.zasyekina@gmail.com orcid.org/0000-0001-8456-0774

Reseracher ID: C-3244-2016
}

Olena Zhuravlova ${ }^{2}$

Ph.D. in Psychology
Олена Журавльова ${ }^{2}$

кандидат психологічних наук

E-mail: aln.frolova@gmail.com orcid.org/0000-0002-4889-0239

${ }^{1}$ National University "Ostroh Academy»

2, Seminarskya Str., Ostroh, Ukraine, 35800

${ }^{2}$ Lesya Ukrainka East European

National University

13, Voli Avenue, Lutsk,

Ukraine, 43025
${ }^{1}$ Національний університет «Острозька академія»

$\bowtie$ вул. Семінарська, 2, Острог, Україна, 35800

${ }^{2}$ Східноєвропейський національний університет імені Лесі Украӥнки $\triangle$ пр. Волі, 13, Луцьк, Україна, 43025

Original manuscript received June 25, 2018

Revised manuscript accepted October 11, 2019 


\section{ABSTRACT}

Objectives. The aim of the study is to examine the procrastination among international students in academic settings in Ukraine.

Materials \& Methods. The 41 participants were recruited from two national universities in Volyn oblast who came from African countries to obtain higher education in Ukraine. Procrastination Scale, Acculturative Stress Scale, Foreign Language Classroom Anxiety Scale were applied in the research.

Results. Evidence consistently suggests that there are no gender differences in procrastination, acculturating stress, and language anxiety. However, a weak negative correlation between procrastination and age of the participants was found $(r=-0.26$ $p<0.05)$. It is possible to hypothesise that academic procrastination is less likely to occur in mature age, being replaced by the procrastination in other life domains. The findings of multiple regression suggest that acculturative stress and language anxiety taken together predict procrastination of the international students $\left(R^{2}=0.469\right.$, $F(4,37)=2.741, p=0.015)$. However, amongst other predictors only fear of negative evaluation as a separate scale of language anxiety is an independent robust predictor of procrastination. One unanticipated finding was that accultuarion is not a significant moderator of the interaction between fear of negative evaluation and procrastination. Therefore, international students' procrastination is predicted by rather social anxiety of being evaluated than cultural settings and language anxiety per se. This inference is in line with the evidence that test anxiety and communication apprehension are not independent significant predictors of procrastination.

Conclusion. The current study showed that the main predictor of procrastination is linked to social anxiety which might be triggered by new cultural and academic settings and, therefore, transformed into procrastination. However, with a small sample size which represents only African students, caution must be applied, as the findings might not be extrapolated for the international students from other countries. Further studies, which take these limitations into account, will need to be undertaken.

Key words: procrastination, acculturating stress, and language anxiety, international students, academic settings, fear of negative evaluation.

\section{Introduction}

A key aspect of procrastination among students is academic procrastination. Several theories on the origin of procrastination have been proposed, irrational and spontaneous delay in performing essential activity (Balkis \& Duru, 2019; Haghbin 2015; Steel \& Ferrari, 2013); low adjustment accompanied with passive, dysfunctional activity (Klingsieck, 2013); non-adaptive behavioral strategy (LindblomYlänne et al., 2015) amongst others. The existing body of research on procrastination suggests that procrastination occurs with comorbidities 
frequently represented by anxiety, depression and fear (Tibbett \& Ferrari, 2015). Recently investigators have also examined the association between procrastination and psychosomatic disorders, notably headaches, immune problems and chronic pain (Klingsieck 2013; Sirois \& Pychyl, 2013), interpersonal problems (Goldin, Katz \& Kuziemko, 2006), and financial difficulties (Gamst-Klaussen, Steel \& Svartdal, 2019).

Data from several studies suggest that there is a significant growth of procrastination among adult population (Markiewicz, 2018). According to this study, about $25.0 \%$ of the general population suffers from chronic procrastination, among them $80.0 \%-90.0 \%$ of students who experience the academic procrastination; as a result $50.0 \%$ of them argue that procrastination has a poor impact on their academic achievements.

It has previously been observed that increased stress in students' academic activity has a poor effect on their academic achievements and exacerbate a chronic or debilitating delay in performing their activity. In contrast to academic procrastination in general, there is much less information about effects of acculturating stress and language anxiety on procrastination among the foreign students.

Therefore, the aim of the study is to analyze theoretical foundations and empirical data providing the idea that the difficulties with acculturation and language barriers could be the robust predictors of procrastination among international students in the academic settings. In particular, we will focus our attention on the effects of acculturative stress and foreign language classroom anxiety on the international students' procrastination. Furthermore, considering the predictors of procrastination might prevent the international students from delaying their academic activity and obtaining low academic achievements.

Acculturation is a process of dual nature containing the essential cultural and psychological transformations as a result of interaction of two or more cultural groups (Berry, 2005). Recent work by psychologists on the problem of acculturation has established that it comprises four stages, euphoria excitement, culture shock negativity, gradual recovery and assimilation amongst others. The stages are characterized by the particular processes, notably initial enthusiasm for everything new and unusual in the host culture; growth of anxiety and intolerance to the uncertainty; awareness of differences and similarities in both cultures; and full acceptance and efficient adjustment to a new cultural environment. 
Existing research recognises the critical role in efficient acculturation played by cognitive and behavioral strategies for cultural adjustment, awareness, learning and adaptation amongst others (Winkelman, 1994).

Previous research comparing cultural shock in the acculturation process and academic achievements of international students apply the 'cultural synergy framework' (Zhou, Jindal-Snape, Topping \& Todman, 2008) and have found that cognitive, affective and behavioral issues of adaptation should be considered. Behavioral adaptation is viewed as a close interaction of the international students with the host students and the host population in general. Cognitive adaptation is linked to the international students' perception of inter-group interaction, perception of discrimination in particular. Affective adaption refers to the international students' well-being which is closely linked to the relationships with host population.

Data from several studies suggest that the foreign students from Asia are characterized by lower level of acculturation than European students since they experience the greater cultural shock based in the deep cultural differences in the environments (Lowinger, He, Lin \& Chang, 2014).

Since the cognitive, affective, and behavioral aspects of adaptation refer to efficient interaction, the language competence plays the primary role in all stages of acculturation. It has previously been observed that communication apprehension, test anxiety and fear of negative evaluation are the robust predictors of poor language integration and together constitute the language anxiety (Horwitz, 2001). Moreover, language anxiety has a poor impact on the academic achievements of the international students. The language anxiety is closely linked to the foreign language acquisition and defined as a specific form of anxiety which is different from the anxiety as a personal trait. The main strategies for coping with language anxiety are self-development or avoidance. In our opinion, the avoidance could be associated with procrastination and, resulted in low academic achievements.

In general, therefore, it seems that difficulties of acculturation and language anxiety could be the serious barriers for efficient interaction of international students with the host peers and exacerbate the delay in their academic activity transforming in procrastination. 
The main research questions of the research:

RQ1: Is there an association between age and procrastination, acculturating stress and language anxiety?

RQ2: Are the high acculturative stress and the foreign language classroom anxiety the predictors of the international students' procrastination?

RQ3: What are the most robust predictors of international students' procrastination?

\section{Methods and techniques of the research}

\section{Participants}

Participants were African students (Nigeria, Ghana, Zimbabwe, Namibia, Senegal) recruited from two Ukrainian universities in Volynskya oblast: Lesya Ukrainka East European National University and Lutsk National Technical University $(\mathrm{n}=41), 29.0 \%$ female $(\mathrm{n}=12)$, $71.0 \%$ male $(\mathrm{n}=29)$. Participants' mean age was $25.14(S D=2.6$ years $)$. Measures

Procrastination was measured by Procrastination Scale (Lay, 1986). The scale has 20 items. The psychometric properties of the scale were assessed, particularly Cronbach alpha of 0.82 and a retest reliability of 0.80 (Hasanagic \& Ozsagir, 2018).

Acculturation was tested with Acculturative Stress Scale (Sandhu \& Asrabadi, 1998). The scale consists of 36 items to assess discrimination, homesickness, fear, guilt, perceived hatred, and general stress as indicators of acculturative stress. The total score ranges from 30 to 180 , where the higher score indicated the deeper stress. The results of principle components method indicated that six factors are accounting for $70.6 \%$ of the total explained variance. Strong evidence of predominance of perceived discrimination was found, since it covers the highest perscentage amongst other factors (38.3\%). Further statistical tests revealed the alpha reliability statistics for this sample were perceived discrimination, 0.87; homesickness, 0.68; fear, 0.70; and culture shock \& stress, 0.56 .

The language anxiety was tested by the foreign language classroom anxiety scale (Horwitz, Horwitz \& Cope, 1986). The scale consists of 33-items and assess communication apprehension, test anxiety, 
and fear of negative evaluation. Internal consistency, as measured by Cronbach's alpha coefficient, was 0.93 , and test-retest reliability over 8 weeks was $\mathrm{r}=0.83, \mathrm{p}=0.001, \mathrm{n}=78$ (Horwitz, 1986).

The majority of classes for international students were taught in Ukrainian, which is foreign language for them. Ukrainian is quite distant for students' native English which is characterized by analytic nature. Ukrainian is East Slavic language of a fusional character. It means that Ukrainian in contrast to English from Germanic branch is a type of synthetic language, distinguished from agglutinative languages by their tendency to use single inflectional morphemes to denote grammatical, syntactic or semantic features. The canonical word order of Ukrainian is Subject-Verb-Object. Other word orders are usual due to the free world order created by Ukrainian's inflectional system.

In Ukrainian language nouns have seven cases: nominative, accusative, genitive, dative, instrumental, and locative, vocative; whereas in English only three cases are distinguished: nominative, genitive and accusative. However, both languages have two numbers: singular and plural. In Ukrainian adjectives agree with nouns in case, gender and number. Verbs have three tenses in Ukrainian language: past, present and future and two voices: active and passive. They are differentiated into three persons: first, second and third; and two numbers: singular and plural. Ukrainian verbs can be classified into two kinds: perfective and imperfective. These kinds are formed by prepositional prefixes or root changes. The verbs in the past tense are agreed with the subject in number and gender, originated from the perfect participle. The English verbs have simple, continuous and perfect tenses within present, past and future. Therefore, the great grammatical differences in Ukrainian and English language form difficulties for international students in the academic settings and could have a poor impact on the development of language anxiety.

Statistical procedure. The statistical analysis used to process the data included correlation and multiple regression, moderation analysis in particular based on IBM SPSS statistics 21 .

\section{Results}

The means and standard deviations for the study are given on Table 1. 
Акультураційний стрес, мовна тривожність та прокрастинація...

Table 1. Means and standard deviations for all subjects $(n=41)$ and $t$-test differences between males $(n=29)$ and females $(n=12)$

\begin{tabular}{lcccccccc}
\hline & \multicolumn{2}{c}{ Total } & $(\mathbf{n}=\mathbf{4 1})$ & \multicolumn{2}{c}{ Males } & $(\mathbf{n}=\mathbf{2 9})$ & \multicolumn{2}{c}{ Females } \\
(n=12) & & \\
\hline Variables & M & SD & M & SD & M & SD & t & p \\
\hline Procrastination & 52.67 & 1.52 & 52.66 & 14.89 & 52.66 & 7.27 & 0.000 & 1.000 \\
PD & 22.19 & 1.17 & 21.90 & 8.55 & 22.91 & 4.70 & 0.492 & 0.626 \\
H & 12.36 & 0.59 & 12.10 & 3.95 & 13.00 & 3.54 & 0.719 & 0.480 \\
PH & 12.66 & 0.80 & 12.40 & 5.57 & 13.33 & 4.29 & 0.582 & 0.565 \\
F & 8.79 & 0.56 & 8.77 & 4.04 & 8.83 & 2.51 & 0.064 & 0.949 \\
CS & 8.07 & 0.46 & 7.80 & 3.11 & 8.75 & 2.49 & 1.037 & 0.310 \\
G & 4.79 & 0.37 & 4.83 & 2.50 & 4.67 & 2.42 & 0.197 & 0.846 \\
M & 24.14 & 1.29 & 23.83 & 9.32 & 24.91 & 5.43 & 0.468 & 0.643 \\
AS & 93.00 & 4.43 & 91.63 & 32.04 & 96.41 & 18.21 & 0.599 & 0.553 \\
CA & 29.07 & 1.21 & 28.50 & 7.80 & 30.50 & 8.21 & 0.724 & 0.428 \\
TA & 38.61 & 1.39 & 38.00 & 7.95 & 40.00 & 11.52 & 0.532 & 0.602 \\
FNE & 16.38 & 0.95 & 16.03 & 6.20 & 17.25 & 6.30 & 0.568 & 0.576 \\
LA & 84.07 & 3.30 & 82.60 & 20.21 & 87.50 & 24.57 & 0.568 & 0.576 \\
\hline
\end{tabular}

PD perceived discrimination, $\mathrm{H}$ homesickness, $\mathrm{PH}$ perceived hate, $\mathrm{F}$ fear, $\mathrm{G}$ guilt, $\mathrm{M}$ miscellaneous, CS cultural shock, AS acculturative stress CA communication apprehension, TA test anxiety, FNE fear of negative evaluation, LA language anxiety

The data of descriptive statistics is in line with other studies in the field (Lowinger et al., 2014). It is apparent from this table that there are no gender differences concerning procrastination, acculturation and language anxiety in international students.

Table 2 represents the results of the correlation analysis. The results of the Pearson moment correlation indicate that there is a weak negative correlation between age and procrastination. It is apparent from this table that procrastination can decline within the life span. The results are in line with the study which underlined the age 14-29 as the most vulnerable for procrastination (Beutel et al., 2016), whereas in the older age the procrastination is declining.

RQ2 and RQ3 were tested by multiple regressions and moderation analysis. Multiple regression analysis has been used to predict of value of procrastination based on values of independent variables of perceived discrimination, homesickness, perceived hate, fear, guilt, miscellaneous, cultural shock, communication apprehension, test anxiety, fear of negative evaluation, and language anxiety. 
Table 2. Correlation (2-tailed Pearson $r$ ) between age and procrastination, acculturative stress, language anxiety

\begin{tabular}{cccc}
\hline & P & AS & LA \\
\hline Age & $-0.26^{*}$ & 0.19 & 0.25 \\
\hline
\end{tabular}

Note: ${ }^{*} \mathrm{p}<0.05 ; * * \mathrm{p}<0.01$.

$\mathrm{P}$ procrastination, AS acculturative stress, LA language anxiety

The assumptions of linear relationship between each independent variable and dependent variable were tested through simple scatterplots and partial regression plots. The independence of residuals was assessed by Durbin Watson $(\mathrm{d}=1.31)$. The assumption of multicolleniarity was also met, since tolerance for all predictors $>0.1$, and $1<\mathrm{VIF}>10$. Assumption of homoscedasticity was controlled by scatterplot ZRESID vs. ZPRED. The results indicate that the assumption of homoscedasticity is also met. The histogram also shows the normally distributed errors in the variables.

The results of the regression with enter method show that ten variables (perceived discrimination, homesickness, perceived hate, fear, guilt, miscellaneous, cultural shock, communication apprehension, test anxiety, fear of negative evaluation, and language anxiety) explained $46.9 \%$ of procrastination, $R^{2}=0.469, F(4.37)=2.741, p=0.015$. An unanticipated finding was that only one independent variable (fear of negative evaluation) significantly predicted procrastination (see Table 3 ). Therefore, the result is somewhat counterintuitive. On the one hand, the results of the regression analysis show that all predictors produce the significant model, covering $46.9 \%$ of procrastination; on the other hand, only fear of negative evaluation has an independent significant contribution to the procrastination.

Table 3. Summary of Multiple Regression Analyses for Variables Predicting Procrastination $(\mathrm{n}=41)$

\begin{tabular}{lcccc}
\hline Variables & B & SE B & $\boldsymbol{\beta}$ & t \\
\hline AS & -0.02 & 0.06 & -0.07 & -0.37 \\
CA & 0.50 & 0.35 & 0.40 & 1.60 \\
TA & 0.19 & 0.25 & -0.18 & -0.76 \\
FNE & 0.77 & 0.36 & 0.48 & $2.15^{*}$ \\
\hline
\end{tabular}

Note: ${ }^{*} p<.05 .{ }^{* *} p<.01$

AS acculturative stress CA communication apprehension, TA test anxiety, FNE fear of negative evaluation 
To assess the relationship between fear of negative evaluation and procrastination as function of acculturating stress moderation analysis has been performed. After meeting all assumptions and reducing multicolleniarity by centering two variables and multiplying them to obtain their interaction of acculturating stress and fear of negative evaluation, we found insignificant meaning of moderation. The results are given on Table 4. Therefore, these results suggest that acculturative stress and language anxiety taken together predict procrastination of the international students. However, evidence consistently suggests that amongst other predictors only fear of negative evaluation as a separate scale of language anxiety is an independent robust predictor of procrastination.

Table 4. Linear Model of Predictors of Procrastination with Acculturative Stress in Moderation Analysis $(n=41)$

\begin{tabular}{lcccc}
\hline Variables & $\mathbf{B}$ & $\mathbf{S E} \mathbf{B}$ & $\mathbf{t}$ & $\mathbf{p}$ \\
\hline Constant & 10.65 & 15.50 & 0.69 & $\mathrm{p}=0.50$ \\
FNE & 2.44 & {$[-21.41 ; 42.71]$} & & \\
& & 0.92 & 2.66 & $\mathrm{p}=0.01$ \\
AS & 0.21 & {$[0.54 ; 4.30]$} & 0.16 & $\mathrm{p}=0.20$ \\
AS*FNE & & $0.21 ; 0.58]$ & 1.32 & $\mathrm{p}=0.20$ \\
\hline
\end{tabular}

Note: $R^{2}=0.36$; AS acculturative stress, FNE fear of negative evaluation, AS* FNE interaction of acculturating stress and fear of negative evaluation

\section{Discussion}

As mentioned in the literature review, difficulties in acculturation and low language ability have a poor impact on procrastination in international students. The first question in this study sought to determine gender and age differences of international students' procrastination. With respect to the first research question, it was found that there is a weak negative correlation between procrastination and age of the participants. This finding is consistent with that of Beutel et al. (2016) who revealed the decline of procrastination within the life span and define the most sensitive age for procrastination between 14-29 years. 
A possible explanation for these results may be the lack of adequate study of different life domains of procrastination. The recent research shows that the higher procrastination in educated adults refers to the health domain rather than to the other spheres of life (Hen \& Goroshit, 2018). Since a great deal of previous research into procrastiation has focused on the academic procrastination, the most sensitive age for procrastination is linked to the students' age. Therefore, very little was found in the literature on the question of different domains of procrastination and their associations with the age groups.

In consistency with earlier findings no evidence of gender diffrences was detected. However, previous studies have suggested that perceived discrimination and homesickness are significant predictors of procrastination among males whereas cultural shock and stress are significantly higher in females (Lowinger et al., 2014).

With respect to the second and the third research questions, it was found that perceived discrimination, homesickness, perceived hate, fear, guilt, miscellaneous, cultural shock, communication apprehension, test anxiety, fear of negative evaluation taken together could predict the procrastination. However, the only significant independent predictor is fear of negative evaluation. These results reflect those of Reichenberger, Smyth \& Blechert (2018) who also found that that fear of evaluation is a robust indicater of social anxiety and is exacerbated by feelings of possible downward shifts in social relationships and exclusion from the group. Fear of negative evaluation refers to the core beliefs about self and predict great sensitivity to learning positive and negative evaluation and, therefore, has a poor impact on mental health (Button et al., 2015; Zasiekina, 2015).

One unanticipated finding was that acculturating stress relationship between fear of negative evaluation and procrastination is not moderated by acculturating stress. Therefore, international students' procrastination is predicted rather by social anxiety of being evaluated than cultural settings and language anxiety per se. What is surprising is that procrastination is not associated with the other scales of language anxiety, test anxiety and communication apprehension. However, these results corroborate the findings of a great deal of the previous work in the efficient acculturation of international students which based in interaction with others, host students and populations in particular. Thus fear of negative evaluation as a robust predictor of procrastination may 
be explained by the primary importance of other people for international students. Another possible explanation for this is that procrastination and fear of negative evaluation can be described in terms of general personal traits linked to social anxiety which can serve as a basis for difficulties in efficient acculturation.

\section{Conclusion}

The findings of this research provide insights for association of procrastination, acculturating stress and language anxiety. The investigation has shown that the indices of procrastination for African students in new academic cultural settings are comparatively higher than in Chinese students reported by Lowinger et al. (2014). These results are important in two major respects. Firstly, this research support the idea that the study of international students' procrastination should consider the cultural background of the students. The previous research has also shown that Chinse students can underreported the primary difficulties in their acculturation since they represent the salient culture $(\mathrm{Li}$, Wang \& Fisher, 2004). Secondly, the country which the students have chosen to study in is of crucial importance. The high standards of the developed countries could predict the lower acculturative stress in the international students than developing countries.

This study has raised important questions about the nature of procrastination. Multiple regression analysis revealed that the fear of negative evaluation is an independent significant predictor of the procrastination. Therefore the principal theoretical implication of this study is that procrastination refers to social anxiety, which is exacerbated by new cultural academic settings. The following conclusions can be drawn from the present study that new cultural academic settings and linguistic barriers of foreign language cannot predict procrastination per se, if the students are not vulnerable for social anxiety. This new understanding should help to undermine predictors of procrastination through reducing social anxiety manifestation in international students.

One of the more significant findings to emerge from this study is that procrastination in a new cultural academic environment can be studied within 'cultural synergy framework' (Zhou, Jindal-Snape, Topping \& Todman, 2008). This study has found that generally 
overcoming procrastination in a new academic settings is linked to reducing the fear of negative evaluation. Furthermore, fear of negative evaluation among international students is highly associated with a close interaction with host peers in academic settings and host population in general. Thus, cognitive (improvement of international students' perception of inter-group interaction and discrimination), behavioral (close interaction of the international students with the host students and the host population) and affective strategies (enhancing the wellbeing based on efficient international students' relationships) should be considered to overcome procrastination.

The limitation of the study is that with a small sample size which represents only African students, caution must be applied, as the findings might not be extrapolated for the international students from other countries. Further studies, which take these limitations into account, will need to be undertaken. Large randomised controlled trials with international students from different cultural backgrounds could provide more definitive evidence of assossiation between procrastination and fear of negative evaluation as an indicator of social anxiety. The host universities in Ukraine are strongly recommended to implement supportive programs assessing and reducing social anxiety in international students.

\section{References}

Berry, J.W. (2005). Acculturation: Living successfully in two cultures. International Journal of Intercultural Relations, 29(6), 697-712. https://doi.org/10.1016/j. ijintrel.2005.07.013

Balkis, M., \& Duru, E. (2019). Procrastination and Rational/Irrational Beliefs: A Moderated Mediation Model. Journal of Rational-Emotive \& CognitiveBehavior Therapy, 1-17. https://doi.org/10.1007/s10942-019-00314-6

Button, K.S., Kounali, D., Stapinski, L., Rapee, R.M., Lewis, G., \& Munafò, M.R. (2015). Fear of negative evaluation biases social evaluation inference: Evidence from a probabilistic learning task. PloS one, 10(4), e0119456. https://doi. org/10.1371/journal.pone.0119456

Beutel, M.E., Klein, E.M., Aufenanger, S., Brähler, E., Dreier, M., Müller, K.W., \& Wölfling, K. (2016). Procrastination, Distress and Life Satisfaction Across the age Range-A German Representative Community Study. PloS one, 11(2), e0148054. https://doi.org/10.1371/journal.pone.0148054

Gamst-Klaussen, T., Steel, P., \& Svartdal, F. (2019). Procrastination and personal finances: Exploring the roles of planning and financial self-efficacy. Frontiers in Psychology, 10, 1-10. https://doi.org/10.3389/fpsyg.2019.00775 
Goldin, C., Katz, L.F., \& Kuziemko, I. (2006). The homecoming of American college women: The reversal of the college gender gap. The Journal of Economic Perspectives, 20(4), 133-157. https://doi.org/10.3386/w12139

Haghbin, M. (2015). Conceptualization and operationalization of delay: Development and validation of the multifaceted measure of academic procrastination and the delay questionnaire. Doctoral dissertation. Carleton University. https://doi. org/10.22215/etd/2015-11051

Hasanagic, A., \& Ozsagir, C.B. (2018). The Validity Exploration of General Procrastination Scale (Lay, 1986). Epiphany, 11(1). http://dx.doi.org/10.21533/ epiphany.v11i1.283

Hen, M., \& Goroshit, M. (2018). General and Life-Domain Procrastination in Highly Educated Adults in Israel. Frontiers in psychology, 9, 1173. https://doi. org/10.3389/fpsyg.2018.01173

Horwitz, E.K. (1986). Preliminary evidence for the reliability and validity of a foreign language anxiety scale. Tesol Quarterly, 20(3), 559-562. https://doi. org $/ 10.2307 / 3586302$

Horwitz, E. (2001). Language anxiety and achievement. Annual review of applied linguistics, 21, 112-126. https://doi.org/10.1017/S0267190501000071

Horwitz, E.K., Horwitz, M.B., \& Cope, J. (1986). Foreign language classroom anxiety. The Modern language journal, 70(2), 125-132. https://doi. org/10.1111/j.1540-4781.1986.tb05256.x

Klingsieck, K.B. (2013). Procrastination: When good things don't come to those who wait. European Psychologist, 18(1), 24-34. https://doi.org/10.1027/1016-9040/ a000138

Lay, C.H. (1986). At last, my research article on procrastination. Journal of research in personality, 20(4), 474-495. https://doi.org/10.1016/0092-6566(86)90127-3

Li, J., Wang, L., \& Fisher, K.W. (2004). The organization of Chinese shame eoneepts. Cognition and Emotion, 18(6), 767-797. https://doi. org/10.1080/02699930341000202

Lindblom-Ylänne, S., Saariaho, E., Inkinen, M., Haarala-Muhonen, A., Hailikari, T. (2015). Academic procrastinators, strategic delayers and something betwixt and between: An interview study. Frontline Learning Research, 3(2), 47-62. https:// doi.org/10.14786/flr.v3i2.154

Lowinger, R., He, Z., Lin, M., \& Chang, M. (2014). The impact of academic selfefficacy, acculturation difficulties, and language abilities on procrastination behavior in Chinese international students. College Student Journal, 48(1), 141-152.

Markiewicz, K. (2018). Prokrastynacja i prokrastynatorzy. Definicja, etiologia, epidemiologia i terapia. Annales Universitatis Mariae Curie-Skłodowska, 31(3), 195-213. https://doi.org/10.17951/j.2018.31.3.195-213

Reichenberger, J., Smyth, J.M., \& Blechert, J. (2018). Fear of evaluation unpacked: day-to-day correlates of fear of negative and positive evaluation. Anxiety, Stress, \& Coping, 31(2), 159-174. https://doi.org/10.1080/10615806.2017.1396826

Sandhu, D.S., \& Asrabadi, B.R. (1998). An acculturative stress scale for international students: A practical approach to stress management. Evaluating stress: A book of resources, 2, 1-33.

Sirois, F.M., \& Pychyl, T.A. (2013). Procrastination and the Priority of ShortTerm Mood Regulation: Consequences for Future Self. Social and Personality Psychology Compass, 7(2), 115-127. https://doi.org/10.1111/spc3.12011 
Steel, P., \& Ferrari, J. (2013). Sex, Education and Procrastination: An Epidemiological Study of Procrastinators' Characteristics from a Global Sample. European Journal of Personality, 27(1), 51-58. https://doi.org/10.1002/per.1851

Tibbett, T.P., \& Ferrari, J.R. (2015). The portrait of the procrastinator: Risk factors and results of an indecisive personality. Personality and Individual Differences, 82(2015), 175-184. https://doi.org/10.1016/j.paid.2015.03.014

Winkelman, M. (1994). Cultural shock and adaptation. Journal of Counseling \& Development, 73(2), 121-126. https://doi.org/10.1002/j.1556-6676.1994.tb01723.x

Zasiekina, L. (2015). Psycholinguistic approach to diagnostics and modification of individual negative core beliefs. East European Journal of Psycholinguistics, 2(1), 151-157.

Zhou, Y., Jindal-Snape, D., Topping, K., \& Todman, J. (2008). Theoretical models of culture shock and adaptation in international students in higher education. Studies in higher education, 33(1), 63-75. https://doi.org/10.1080/03075070701794833

\begin{abstract}
АНОТАЦІЯ
Метою статmі $\epsilon$ вивчення прояву прокрастинації в іноземних студентів у навчальних закладах України.

Матеріали і методи. Для дослідження було відібрано 41 респондента, які $\epsilon$ вихідиями з африканських країн і здобувають вищу освіту у двох національних університетах Волинської області. У дослідженні використовувалися шкала прокрастинації, шкали дослідження акультураційного стресу та мовної тривожності при вивченні іноземної мови.

Результати. Фактичні дані свідчать про відсутність гендерних відмінностей у рівнях сорормованості прокрастинації, акультураційного стресу та мовної тривожності. Однак, виявлено слабку негативну кореляцію між прокрастинацією $і$ віком учасників дослідження $(r=-0,26 p<0,05)$. Можна припустити, що академічна прокрастинація рідше зустрічається в зрілому віці, натомість охоплює інші сфери життя. Результати множинної регресії свідчать, що акультураційний стрес в поєднанні з мовною тривожністю $\epsilon$ предиктором прокрастинації іноземних студентів $\left(R^{2}=0,469, \quad F(4,37)=\right.$ 2,741, $p=0,015)$. Проте серед інших діагностованих параметрів лише страх негативної оцінки, як окрема шкала мовної тривожності, $\epsilon$ значущою детермінантою зволікання. Одним із неочікуваних результатів було те, що акультурація не є важливим модератором взаємодії між страхом негативної оцінки і прокрастинацією.
\end{abstract}

Висновки. Прокрастинація іноземних студентів більшою мірою зумовлюється загальним страхом бути оціненим, ніж культурними аспектами і мовною тривогою. Дослідження демонструє, що головний предиктор прокрастинації пов'язаний із сочіальною тривожністю, яка може спонукатися новими культурними і академічними умовами і таким чином трансформуватися у прокрастинацію. Однак при невеликому об'ємі вибірки, представниками якої $\epsilon$ лише арриканські студенти, дослідження має певні обмеження, оскільки отримані дані не можуть бути екстрапольовані на іноземних студентів 3 інших країн. У подальших дослідженнях слід враховані вказані обмеження. 
Акультураційний стрес, мовна тривожність та прокрастинація...

Ключові слова: прокрастинація, акультураційний стрес, мовна тривожність, іноземні студенти, академічні умови, страх негативної оцінки.

Засекина Лариса, Журавлева Елена. Аккультурационный стресс, языковая тревожность и прокрастинация иностранных студентов в академической среде

\begin{abstract}
АННОТАЦИЯ
Цель статьи. Статья посвящена изучению проявления прокрастинации у иностранных студентов в учебных заведениях Украины.

материалы и методы. Для исследования было отобрано 41 респондента, которые являются выходцами из африканских стран и получают высшее образование в двух национальных университетах Волынской области. В исследовании использовались икала прокрастинации, аккультурационного стресса, языковой тревожности при изучении иностранного языка.

Результаты. Фактические данные свидетельствуют об отсутствии гендерных различий в уровнях сформированности прокрастинации, аккультурационного стресса и языковой тревожности. Однако, обнаружена слабая отрицательная корреляцию между прокрастинацией и возрастом участников исследования $(r=-0,26 p<0,05)$. Можно предположить, что академическая прокрастинация реже встречается в зрелом возрасте, охватывая при этом другие сфреры жизни. Результаты множественной регрессии показывают, что аккультурационный стресс в сочетании с языковой тревожностью является предиктором прокрастинации иностранных студентов $(R 2=0,469, F(4,37)$ $=2,741, p=0,015)$. Однако среди других диагностируемых параметров только страх негативной оценки, как отдельная шкала языковой тревожности, является значимой детерминантой промедления. Одним из неожиданных результатов было то, что аккультурация не является важным модератором взаимодействия между страхом негативной оценки и прокрастинацией.
\end{abstract}

Выводы. Таким образом, прокрастинация иностранных студентов в большей степени обусловлена общим страхом быть оцененным, чем культурными аспектами и языковой тревогой. Исследование показывает, что главный предиктор прокрастинации связан с социальной тревожностью, которая может вызываться новыми культурными и академическими условиями и таким образом трансформироваться в прокрастинацию. Однако при небольшом объеме выборки, представителями которой являются только африканские студентыб исследования имеет ограничения, поскольку полученные данные не могут быть екстраполированы на иностранных студентов из других стран. В дальнейших исследованиях обязательно должны быть учтены указанные ограничения.

Ключевые слова: прокрастинация, аккультурационный стресс, языковая тревожность, иностранные студенты, академические условия, страх негативной оценки. 